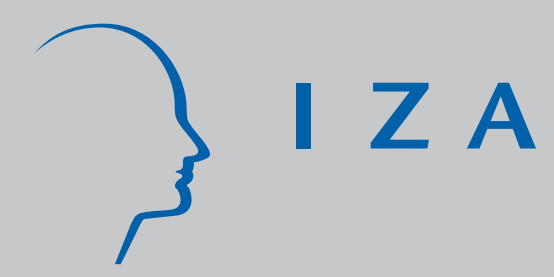

IZA DP No. 175

Self-Employment and Earnings among HighSkilled Immigrants in the United States

Magnus Lofstrom

J uly 2000 


\title{
Self-Employment and Earnings among High-Skilled Immigrants in the United States
}

\author{
Magnus Lofstrom \\ IZA, Bonn
}

Discussion Paper No. 175
July 2000

IZA

P.O. Box 7240

D-53072 Bonn

Germany

Tel.: +49-228-3894-0

Fax: +49-228-3894-210

Email: iza@iza.org

This Discussion Paper is issued within the framework of IZA's research area Mobility and Flexibility of Labor Markets. Any opinions expressed here are those of the author(s) and not those of the institute. Research disseminated by IZA may include views on policy, but the institute itself takes no institutional policy positions.

The Institute for the Study of Labor (IZA) in Bonn is a local and virtual international research center and a place of communication between science, politics and business. IZA is an independent, nonprofit limited liability company (Gesellschaft mit beschränkter Haftung) supported by the Deutsche Post AG. The center is associated with the University of Bonn and offers a stimulating research environment through its research networks, research support, and visitors and doctoral programs. IZA engages in (i) original and internationally competitive research in all fields of labor economics, (ii) development of policy concepts, and (iii) dissemination of research results and concepts to the interested public. The current research program deals with (1) mobility and flexibility of labor markets, (2) internationalization of labor markets and European integration, (3) the welfare state and labor markets, (4) labor markets in transition, (5) the future of work, (6) project evaluation and (7) general labor economics.

IZA Discussion Papers often represent preliminary work and are circulated to encourage discussion. Citation of such a paper should account for its provisional character. 
IZA Discussion Paper No. 175

July 2000

\title{
ABSTRACT \\ Self-Employment and Earnings among High-Skilled Immigrants in the United States*
}

This paper uses data from the 1980 and 1990 U.S. Censuses to analyze the labor market experience of high-skilled immigrants relative to high-skilled natives. Immigrants are found to be more likely to be working in one of the high-skilled occupations than natives, but the gap between the two groups decreased in the 1980's. Given the high self-employment rates of this group of workers, about 20 percent, it is important to study this aspect of the labor market experience. High-skilled natives are more likely to be self-employed than high-skilled immigrants. Models of the self-employment decision, controlling for differences in socioeconomic background, occupation, regional differences in immigrant population proportions, national origin and ethnicity, are estimated. Evidence of positive enclave effects on selfemployment probabilities is found. Predicted earnings of self-employed immigrants are higher throughout most of their work life relative to wage/salary immigrants and natives, as well as compared to self-employed natives. Furthermore, there appears to be very little difference in predicted earnings across national origin group of self-employed immigrants. The low variation in predicted earnings across country of origin groups is not found for wage/salary immigrants.

JEL Classification: J15, J23, J61

Keywords: Immigration, assimilation, self-employment, high-skill

\author{
Magnus Lofstrom \\ IZA \\ P.O. Box 7240 \\ D-53072 Bonn \\ Germany \\ Tel.: +492283894303 \\ Fax: +492283894210 \\ Email: lofstrom@iza.org
}

\footnotetext{
" I am grateful to Jörgen Hansen, Mark Regets and participants at The Center for Comparative Immigration Studies conference on "The International Migration of the Highly Skilled" in San Diego for helpful comments
} 


\section{Introduction}

The current policy debate about immigration in the U.S. focuses almost entirely on high-skilled workers. The debate regarding an increase in the number of temporary visas given to high-skilled workers, particularly in the information technology sector is not unique to the U.S. In Germany, for example, Chancellor Gerhard Schroeder recently proposed a plan that would give 20,000 high-skilled immigrants 5 year temporary work permits in order to ease the perceived shortage of IT workers. Similar proposals of making temporary work permits more easily available for high-skilled immigrants are taking place in Great Britain, Ireland and even Sri Lanka.

Although the H-1B visa debate concerns only "temporary" immigration, the European experience, in particular the German guest worker program, shows that immigrants who are given temporary work permits are very likely to stay permanently (Dustmann, 1996). This means that we need to have an understanding of how these, so called "temporary", immigrants affect the economy in the long-run. One crucial determinant of this is the success, or lack thereof, of immigrants in the U.S. labor market. That is, how do high-skilled immigrants perform in the U.S. labor market relative to highskilled natives? No previous study in the economics of immigration literature has analyzed this issue for this group of immigrants. Instead, an implicit assumption has been made that highly educated immigrants are relatively successful, as compared to natives, in the labor market. Furthermore, about one in five high-skilled males are self-employed in the U.S. This is true for both natives and immigrants. Therefore, to get an accurate picture of labor market performance of high-skilled immigrants it is necessary to both include the self-employed and to analyze the decision to become self-employed. 
This paper looks closely at the labor market performance of the group of immigrants currently in the U.S. who are most likely to resemble the inflow of immigrants under the H-1B visa, i.e. high-skilled immigrants. To obtain an accurate prediction of this group's performance in the labor market it is necessary to use a large representative sample containing detailed individual background information on variables such as education, occupation, geographic location, age, time of arrival in the U.S. and earnings. The only currently available data set that satisfies these criteria for this minority group of immigrants, i.e. high-skilled immigrants, is the U.S. Census.

The paper uses data from the 1980 and 1990 U.S. Censuses to show what occupations the high-skilled immigrants work in, their self-employment rates and differences in the proportion of high-skilled immigrants by national origin group. I also model the selfemployment decision taking into account differences in socio-economic background, occupation, regional differences in immigrant population proportions, national origin and ethnicity. The data shows that immigrants are more likely to be working in one of the high-skilled occupations than natives, but that the gap between the two groups decreased in the 1980's. It also shows that high-skilled natives are more likely to be self-employed than immigrants. Self-employment rates for high-skilled immigrants appear to vary less between national origin groups than they do among immigrants overall. Higher proportions of co-nationals or co-ethnics in an area, so called enclaves, seem to increase the probability a highly skilled individual selects self-employment. The estimates from the self-employment decision model are used to control for self-selection into selfemployment and wage/salary work in the estimated earnings functions. 
The estimated earnings functions are used to generate sector specific measures of labor market assimilation. I find that both self-employed and wage/salary immigrants are likely to reach earnings parity with natives, although the result vary somewhat between immigrant country of origin. However, earnings of self-employed immigrants appear to be higher throughout most of their work life when compared to the earnings of both wage/salary and self-employed natives. Furthermore, there appears to be very little difference in predicted earnings across national origin group of self-employed immigrants. For example, self-employed Mexican high-skilled immigrants, although a small group of Mexican immigrants, are predicted to do as well in the U.S. labor market as European self-employed immigrants. The low variation in predicted earnings across country of origin groups is not found for wage/salary immigrants.

The paper is organized in the following way. Section 2 describes the data used. Section 3 outlines and compares traits of immigrants and natives in the two sectors. In Section 4, the self-employment decision model is described and Section 5 shows the empirical results. Earnings equations are presented in Section 6. Age-earnings profiles are also derived and discussed in this section. Finally, Section 7 concludes and summarizes the results of the study.

\section{Data}

The data used in this paper are drawn from the 1980 5\% A Sample and the $19905 \%$ Sample of the U.S. Census of Population. The study includes males between the ages of 22 and 64 who are not residing in group quarters, who are not in military service or enrolled in school, and who reported working in the year prior to the census. Given the 
extremely large data set this leaves us with, I extracted a 20 percent randomly selected sub-sample of native born Americans from the 5\% Sample, but kept all immigrants. Since the 1990 Census is not a random sample of the population, sampling weights were used. These were set to the appropriate constants for the 1980 Censuses. All weights were then adjusted accordingly since not all observations for natives were used.

The above described sample includes $1,320,091$ observations. From this sample a sub-sample consisting only of individuals in high-skilled occupations was created. The occupations were chosen based on the propensity of individuals in the occupation to be highly educated, where highly educated is defined to be at least a college graduate. The high-skilled occupations were then grouped into 8 groups. The high-skilled occupational groups are Management and Finance, Architecture, Engineering, Computer Sciences, Mathematical and Natural Sciences, Health and Medicine, Social Sciences and Law. The average number of years of schooling for this sub-sample was 16.65 years in 1980 and 16.7 years in 1990. The number of observation in high-skilled occupations is 106,908.

The earnings regressions in this paper use as the dependent variable log of weekly total earnings, where weekly earnings is defined to be the sum of earnings from wage/salary work and self-employment divided by reported weeks worked. This restricts the sample to include only males who reported positive earnings in the year prior to the census. Since the self-employed may report negative earnings and would hence be excluded from the wage regressions, I also estimated the earnings function using weekly earnings as the dependent variable. The general results that are reported in this paper also hold for this measure of earnings. It should also be noted that earnings and income 
reported in the census refers to year prior to the census, i.e. 1979 and 1989 in this paper. Earnings and income has been realized to 1989 dollars by using the CPI.

It is interesting to note that the selection process that determines who migrates or not, and hence the labor market performance of immigrants, is believed to be determined by the relative conditions in host and source country (see for example Borjas, 1987). However, the majority of studies on immigrant performance have been done based on ethnic groups, and not on country of origin. In this paper I try to create 10 relatively homogenous groups based on countries' geographic location and cultural and economic conditions, while maintaining a large enough sample size for each group.

It should be noted that any attempt to create homogenous groups will be scarred by compromises. It is quite clear that there are substantial differences in characteristics such as self-employment rates and educational attainment between immigrant groups, Lofstrom (1999). If the group is defined too widely, the impact of variations in these variables may not be accurately estimated. If the group is too narrowly defined, by country for example, the sample size will be small for some of the countries. This is particularly true when studying the sub-group of high-skilled immigrants. However, if different ethnic groups face different labor market constraints, such as discrimination, creating groups based on national origin may not be the best way to compose groups.

The national origin groups used in this paper are Mexico, Central/South America, South East Asia, North East Asia, India/Pakistan, Europe/Canada/Australia/New Zealand, Africa, Caribbean, Cuba and lastly all other countries of origin. Table A1 in the appendix describes the countries represented in each national group used in this paper. Although immigrants are a heterogeneous group, Lofstrom (1999) shows that the national origin 
groups defined here are quite homogenous within, at least in terms of educational attainment and ethnicity, and appear to be reasonably defined groups.

\section{Descriptive Statistics of High-Skilled Natives and Immigrants}

The proportion and the distribution of workers in high-skilled occupations among natives and immigrants changed in the 1980's. Table 1 shows that the proportion of male natives in high-skilled occupations increased from 7.3 percent in 1980 to 8.5 percent in 1990. Although the proportion of workers in high-skilled occupations is higher for immigrants than natives in both census years, there appears to be a downward trend among immigrants. In 1980, 9.7 percent of immigrants worked in one of the high-skilled occupations. This figure dropped by half a percentage points in the 1980's to 9.2 percent in 1990. Table 1 also shows that more of the high-skilled individuals are working in Management and Finance (1.5 and 2.5 percentage point increase from 1980 to 1990 for natives and immigrants respectively) and in Law (0.7 and 0.2 percentage points) in 1990 than in 1980. The most dramatic increase was, not surprisingly, in the Computer Sciences where the proportion of high-skilled immigrants more than doubled (an increase from 4.1 percent to 9.1 percent). The proportion of high-skilled natives in this occupation category also increased, but not as dramatically as for immigrants (from 5.6 percent to 8.6 percent).

Self-employment rates among high-skilled natives and immigrants are substantially higher than overall self-employment rates, as can be seen in Table 2. Approximately one fifth of all individuals in high-skilled occupations are self-employed. Not surprisingly, self-employment rates vary considerably across occupational groups. Nevertheless, it 
appears that self-employment rates do not differ very much between immigrants and natives within occupational groups. Also, the overall self-employment rates are quite similar for immigrants and natives. However, high-skilled natives are more likely to be self-employed than high-skilled immigrants. Table 2 also shows that the observed increase in overall self-employment rates for both immigrants and natives is due to an increase in the self-employment rates of the relatively less-skilled individuals.

Previous studies of immigrant labor market performance have found that skill levels vary across immigrants from different country of origin, as do self-employment rates (see for example Borjas, 1994 and Fairlie and Meyer, 1996). Table 3 indicates that skill levels vary substantially across national origin groups. For example, only about 1 percent of Mexican immigrants reported in 1990 as working in one of the high-skilled occupations while in the same year nearly one-third of immigrants from India and Pakistan were highskilled. Although there is large variation in the proportions of high-skilled workers between countries of origin, there is substantially less variation in self-employment rates of the high-skilled across national origin groups. If we exclude Cubans, of whom 30 percent of the high-skilled are self-employed, self-employment rates vary from 13.7 percent for high-skilled African immigrants to 20.6 percent for the Central/South American and Middle Eastern national origin groups.

Immigrants in the U.S. have been found to be less successful in the labor market than natives in the 1980's (Borjas, 1995 and Betts and Lofstrom 2000). Notably, the selfemployed are excluded from these studies. Lofstrom (1999) however includes the selfemployed in his study and finds that self-employed immigrants do better in the labor 
market than wage/salary immigrants and are also likely to reach earnings parity with selfemployed natives.

The relative success of self-employed immigrants, compared to natives and wage/salary immigrants, also appears to hold for the high-skilled self-employed immigrants, as can be seen in Table 4. High-skilled self-employed natives reported 12 percent lower annual income than their self-employed immigrant counterpart in 1989. Wage/salary natives in high-skill occupations reported an income disadvantage of 2 percent in 1989, relative to wage/salary immigrants. Furthermore, self-employed immigrants in less-skilled occupations also reported similar, or slightly higher, income levels to those of natives in 1989. Wage/salary immigrants in the relatively less-skilled occupations earned 22 percent less than natives in the same occupations.

Wage/salary and self-employed immigrants in both high-skill and less-skilled occupations displayed lower relative income, compared to natives, in 1989 than they did in 1979. It appears that the decline in immigrant labor market performance relative to natives is not unique to the less-skilled immigrants. However, as can be seen in table 4, the relative income decline of high-skill immigrants in the 1980's did not take place in all occupation groups. For example, immigrant computer scientists reported improvements in relative income in the 1980 's.

The next two section of this paper will outline a model of the self-employment decisions and report the results from estimating the model using the above described data. Mean characteristics for the dependent and independent variables are shown in Table 5. 


\section{The Self-Employment Decision}

This section outlines the model and the explicit assumptions made in the model of a person's choice of whether to become self-employed or to work in the wage/salary sector. Individuals choose between participation in the wage/salary sector of the labor market and self-employment. The decision will depend on several factors that determine expected utility in each sector. In this paper I assume that the utility function is a function of expected earnings, $y_{\mathrm{i}}^{\mathrm{se}}$ for self-employment work and $y_{\mathrm{i}}^{\mathrm{w} / \mathrm{s}}$ for work in the wage/salary sector, and that the function also indicates preferences for the characteristics of work in the two sectors, denoted $z_{\mathrm{i}}$. Furthermore, earnings in each sector will depend on a vector of observable characteristics, $X_{i}$ and unobserved characteristics $\varepsilon_{i}$. Note that the characteristics $z_{i}$ are assumed to affect utility but not earnings in each sector. Assuming that individuals maximize expected utility, a person will chose self-employment if the expected utility from self-employment, denoted $E\left(u_{\mathrm{i}}^{\mathrm{se}}\right)$, is greater than the expected utility in the wage/salary sector, represented here by $E\left(u_{\mathrm{i}}^{\mathrm{w} / \mathrm{s}}\right)$. Expected utility in the two sectors can be defined as:

$$
\begin{aligned}
& E\left(u_{i}^{w / s}\right)=z_{i}^{w / s} \lambda^{w / s}+y_{i}^{w / s}=z_{i}^{w / s} \lambda^{w / s}+\mathrm{X}_{i} \beta^{w / s}+\varepsilon_{i}^{w / s} \\
& E\left(u_{i}^{s-e}\right)=z_{i}^{s-e} \lambda^{s-e}+y_{i}^{s-e}=z_{i}^{s-e} \lambda^{s-e}+\mathrm{X}_{i} \beta^{s-e}+\varepsilon_{i}^{s-e}
\end{aligned}
$$

where $\varepsilon^{w / s}$ and $\varepsilon^{s-e}$ are jointly normally distributed with mean zero and variances $\sigma_{w / s}^{2}$ and $\sigma_{s-e}^{2}$. An individual chooses self-employment if:

$$
I_{i}^{*}=E\left(u_{i}^{s-e}\right)-E\left(u_{i}^{w / s}\right)>0
$$


Clearly the index function $I_{i}^{*}$ is unobservable. However, from equations (1), (2) and (3) $I_{i}^{*}$ can be defined as:

$$
\begin{aligned}
I_{i}^{*} & =E\left(u_{i}^{s-e}\right)-E\left(u_{i}^{w / s}\right) \\
& =\mathrm{X}_{i} \beta^{s-e}-\mathrm{X}_{i} \beta^{w / s}+z_{i}^{s-e} \lambda^{s-e}-z_{i}^{w / s} \lambda^{w / s}+\varepsilon_{i}^{s-e}-\varepsilon_{i}^{w / s} \\
& =W_{i} \pi+e_{i}
\end{aligned}
$$

If we set $I=1$ if $I_{i}^{*}>0$, if self-employment is chosen, and $I=0$ if $I_{i}^{*} \leq 0$, if the wage/salary sector is selected, then equation (4) can be seen as a probit model of sectoral choice of self-employment.

Estimating the self-employment decision in equation (4) has two main benefits. The first is that it will give us insight to the role of the different characteristics in the choice of sector. The question that can be answered through this process is: What are the reasons for the differences in self-employment rates between immigrants and natives and what are the roles of the factors? The second advantage is that from the probit estimates, when the instruments $z_{\mathrm{i}}$ are included in the model, the inverse Mills ratio can be calculated. This will help to correct for self-selection problems when estimating the earnings functions through use of the Heckman two-step procedure.

\section{Estimation Results: The Self-Employment Decision}

The sectoral choice, wage/salary or self-employment sector, an individual makes will depend on several factors. As explained above, an individual is assumed to compare the expected utility from work in the self-employment sector to the expected utility from employment in the wage/salary sector. If this difference is positive, the individual chooses to be self-employed. The model to be estimated by probit is: 


$$
I_{i}^{*}=W_{i} \pi+e, \text { where } e \sim \mathrm{N}(0,1)
$$

The probability an individual chooses self-employment is:

$$
\operatorname{Prob}\left[I_{i}=1\right]=\Phi(W \pi), \text { where } \Phi(\cdot) \text { is the standard normal cumulative density }
$$

function. The probability a person chooses the wage/salary sector is then simply:

$$
\operatorname{Prob}\left[I_{i}=0\right]=1-\Phi(W \pi)
$$

The choice of sector will likely depend on socio-economic characteristics such as age, education, marital status, disability, and geographic location. If there are differences in the impact any of these variables have on earnings, we would expect these variables to affect the self-employment decision. Factors that may affect the expected utility of an individual, but not an individual's earnings directly, will also influence the selfemployment decision and need to be controlled for. The estimated marginal effects for different variations of the above described model are presented in Table 6. The marginal effects are calculated based on the sample means for continuous variables and for a discrete change of indicator variables from 0 to 1.

High-skilled natives are on average about 2 percent more likely to be self-employed than high-skilled immigrants, as shown in Table 5. To test whether this difference is due to observable socio-economic characteristics, a model including the above discussed traits, a period effect dummy variable for 1980 and an indicator variable for immigrants was estimated. The results are presented as Model 1 in Table 6. The estimated difference between immigrants and natives increases to 5.7 percent when these observable characteristics are taken into account. Given the estimated results that age and education affect the self-employment probability positively and the observation that immigrants in 
these occupations are on average older and more educated, it is not surprising that the difference between the two groups increase.

It is quite clear that there are other variables that are not included in Model 1 that will have an effect on an individual's self-employment decision. For example, for immigrants it is likely that the number of years in the U.S. and the time of arrival in the U.S will also influence this decision. Pooling data from the two census years allows for identification of the effect of both years since migration and arrival cohort. In other words, we can estimate differences in self-employment probabilities across cohorts controlling for years spent in the U.S. Model 2 in Table 6 shows the results when these factors are included in the model. Interestingly, it appears that immigrants who arrived in the 1970's and early 1980's are the most likely high-skilled immigrants to select self-employment, holding all other traits constant. Furthermore, as expected, time spent in the U.S. has a positive effect on the probability of choosing self-employment.

The models discussed so far are quite restrictive in the sense that they do not allow for different effects of the observable characteristics on the self-employment decision for immigrants and natives. Furthermore, one of the reasons for estimating the probits of the self-employment decision is to derive a selection correction term for choosing selfemployment, i.e. to calculate the inverse Mills ratio. The objective in doing so is to reduce the possible selection bias that may arise in the estimated earnings models. The goal is to include in the probit model variables that will influence the self-employment decision, but that will not affect earnings, i.e. some characteristics $z_{\mathrm{i}}$ from the selfemployment decision model above. It is highly desirable, but not necessary, for the probit model to include instruments that help to predict self-employment but which do not 
belong directly in the earnings function. Models 3 and 4 in Table 6 include the instruments used in this paper and also allow for different marginal effects of the observables for immigrants and natives. In addition, these models control for any changes in the estimated parameters over the decade studied by interacting all variables with the 1980 period effect. Controls for country of origin group and ethnicity are also incorporated. Model 4 adds indicator variables for occupations. The role and the estimated results of the instruments tried in this paper are discussed next.

The first instrument used is a variable to test whether immigrants living in areas where relatively many co-nationals reside, so called enclaves, may be the reason we observe higher self-employment rates for some immigrant groups. The sociology literature commonly speaks of ethnic resources as a determinant in an individual's choice of whether or not to choose self-employment (see for example Light, 1984 and Aldrich and Waldinger, 1990). Examples of ethnic resources are skills or knowledge to provide services or goods to other co-ethnics or co-nationals, availability of low wage labor, social support networks that assist an individual in obtaining necessary start-up capital or in transferring managerial skills. Aldrich and Waldinger (1990) describe "opportunity structures" as market conditions that may favor goods or services oriented towards coethnics or co-nationals. Immigrants who are living in areas with relatively high proportions of co-nationals may have a comparative advantage in providing certain goods or services, food or restaurant services for example, to their co-nationals compared to natives or other immigrants. The result, according to this theory, is higher selfemployment rates among immigrants living in enclaves. To allow for the possibility that 
native co-ethnics may also have an advantage similar to that of immigrant co-nationals, a native ethnic enclave variable is also included in the analysis.

The enclave variables are added to Models 3 and 4 in Table 6. The immigrant enclave variable represents the proportion of immigrants in the census year of the total population by SMSA and country of origin. This is calculated by adding up the number of male immigrants in the sample from a particular country in the SMSA and then dividing this by the total male population in the sample in the SMSA. For immigrants living in a nonSMSA area, the proportion is calculated based on the state's non-SMSA immigrant population. Given the definition above, it follows that the value of this variable is zero for all natives. The enclave variable for natives is calculated in the same fashion, but using the 5 ethnic groups whites, blacks, Asians, Hispanics and others. The variable is set to zero for all immigrants.

The estimated coefficients of the enclave variables are positive and significant. This indicates that immigrants living in an area where a greater proportion of co-nationals are living, increases the probability of self-employment. Model 4 shows that although the effect is significantly positive for natives as well, it is only about one third of the effect for immigrants. The results suggest that on average, an increase in the proportion of conationals in the SMSA where the immigrant resides increases the probability of choosing self-employment by about 0.1 percent. The effect for natives from an increase in the proportion of co-ethnics is about 0.03 percent. It appears that both immigrants and natives are positively influenced by an inflow of respective co-nationals and co-ethnics. 
These results suggest that previously found positive enclave effects also hold for high-skilled individuals. That is, it is not only small shops and restaurants that are created by the inflow of immigrants, but also high-skilled firms.

It is also possible that individuals are affected by their co-nationals' and co-ethnics' success as entrepreneurs in deciding whether or not to become self-employed. To control for this possibility two instruments measuring the ratio of self-employment earnings to wage/salary earnings are included. The first variable is calculated by dividing the average native self-employment earnings in the SMSA in a given census year by the average native wage/salary earnings in the same SMSA, by natives' ethnicity. The second variable measures the same ratio, but for immigrants by SMSA and national origin group. The latter variable is set to zero for all natives and the former is set to zero for all immigrants. It is expected that higher self-employment earnings to wage/salary earnings ratios are associated with higher self-employment rates, given a set of individual characteristics, since it essentially measures the relative success of the self-employed in the area ${ }^{1}$. The signs of both of the estimated coefficients are positive, as expected, and significant. However, the impact of a change in the earnings ratio on the probability of self-employment appears to be stronger for natives than immigrants.

Light (1984) argues that differences in traditions of commerce among immigrants from different countries help explain differences in self-employment rates among immigrants in the U.S. This may be one of the reasons for variations in self-employment rates over countries of origin that is not captured by the observable traits in the model.

\footnotetext{
${ }^{1}$ One concern with incorporating these variables into the self-employment decision models is that they may be determined endogenously and consequently lead to inconsistent estimators. However, given that the ratios are relative group characteristics by SMSA and not individual characteristics, this seems somewhat
} 
Also, if immigrants experience discrimination in the labor market and if discrimination varies over source countries, this also needs to be controlled for in the model. To attempt to incorporate these country specific unobservables, dummy variables for the national origin groups are included in Models 3 and 4. The estimated coefficients on the national origin group variables, not shown in tables in order to keep the length of the tables reasonably short, indicate that there is virtually no difference in the probability an individual selects self-employment across national origin groups, holding all observable characteristics constant. The exception is that high-skilled immigrants from South East Asia are slightly less likely to choose to become entrepreneurs compared to statistically similar immigrants from the Middle East. Furthermore, there is no statistical difference in the self-employment probability of high-skilled whites, blacks, Asian and Hispanics.

These results should not be interpreted as that there are no differences in selfemployment propensities between immigrants from different countries or across individuals of different ethnicity. It means that once we condition our sample on being highly skilled, there are small differences across these groups. Several earlier studies have shown, using population representative samples, that both self-employment rates and earnings vary across national origin groups (e.g. Camarota, 2000, Fairlie and Meyer, 1996, Lofstrom, 1999 and Yuengert, 1995). It is however very interesting to note that there is very little variation across high-skilled immigrant and ethnic groups.

As mentioned above, one of the advantages of estimating a model of the selfemployment decision model is that the estimates can be used to control for self-selection in the earnings models. The consistent estimates obtained from the earnings models can

unlikely. The earnings ratio is not clearly endogenous, but may simply reflect entrepreneurial conditions or opportunities in an area. 
then be used to derive age-earnings profiles. From these profiles, we can answer the question if immigrants' earnings are likely to converge with the earnings of natives' over the work-life. The specification in Model 4 is used for the two-step Heckman selection correction models estimated and described below.

\section{Estimation Results: Labor Market Assimilation}

Immigrants' earnings in the wage/salary sector have been found to not converge with natives' earnings (Borjas, 1985 and 1995) over the work life. Earnings of immigrants start out at a lower point and rise more rapidly over time than natives' earnings. However, parity is not reached. The labor market performance of self-employed immigrants, who are excluded from Borjas' studies, have been found to be significantly different from wage/salary immigrants. Lofstrom (1999) finds that earnings of self-employed immigrants is predicted to converge with native wage/salary earnings at around age 30 and native self-employed earnings at around age 40. This section will look at the labor market success of high-skilled immigrants in both the wage/salary and self-employment sector.

The earnings models estimated in this paper use as the dependent variable log of weekly earnings. To try to take into account the possibility that self-employed workers earn a return on physical capital, I also estimate models using as the dependent variable the log of weekly income, which includes any earnings from wage/salary work and/or self-employment earnings and in addition, any interest, rental or dividend income. If an individual is deciding between a wage/salary job or self-employment, he can keep his assets in, for example, savings accounts, the stock market, bonds, or real estate and work 
in the wage/salary sector. Alternatively he can use a proportion, or all, of his assets to start a business. In the former, returns to physical capital will be observed in terms of interest, rental or dividend income. If self-employment is chosen, returns may show up both in increased earnings and interest, rental or dividend income. Therefore, as an alternative outcome measure, I use log income, where income is sum of total earnings and interest, rental or dividend income. With this measure, both groups are put on "par", and this measure of income can be compared reasonably between the two sectors. As stated above, the models estimated in this paper were also estimated using weekly earnings, as opposed to log weekly earnings. It appears that the results are not very sensitive to whether log earnings, log income or weekly earnings are used. In light of this, I use the log of weekly earnings as the dependent variable in all wage regressions presented and discussed in this paper. Furthermore, all earnings are deflated to 1989 dollars using the CPI.

One convenient way of analyzing labor market assimilation is to estimate earnings equations and use the estimated coefficients to trace out age-earnings profiles. The wage models are estimated separately for the self-employed and the wage/salary workers. The regressions are specified as:

$$
\begin{aligned}
& \log y_{i}^{s-e}=\mathbf{X}_{i} \beta^{s-e}+\mathbf{A}_{i} \boldsymbol{\delta}^{s-e}+\mathbf{Y S S M}{ }_{i} \gamma^{s-e}+u_{i}^{s-e}, \quad \text { for the self-employed } \\
& \log y_{i}^{w / s}=\mathbf{X}_{i} \beta^{w / s}+\mathbf{A}_{i} \delta^{w / s}+\mathbf{Y S M}_{i} \gamma^{w / s}+u_{i}^{w / s}, \quad \text { for wage/salary workers }
\end{aligned}
$$

where $\mathbf{X}$ is a vector of socio-economic and geographic characteristics, including dummy variables for immigrant status, national origin group and arrival cohort, $\mathbf{A}$ is a vector of age variables, i.e. age and age $^{2}$, and YSM is a vector of years since migration variables, i.e. YSM and $\mathrm{YSM}^{2}$. The vector $\mathbf{A}$ also includes the age variables interacted with an 
immigrant dummy variable. The years since migration variable is equal to zero for all natives.

The models described above were estimated both by ordinary least squares with no selection correction and also by heteroskedastic robust ordinary least squares using the inverse Mills ratio to correct for selection bias. The estimated coefficients from the earnings models are presented in Tables 7 and 8 where Models 1,2 and 3 are the equations without selectivity correction and Model 4 includes the correction term calculated based on estimation of Model 4 in Table 6.

Self-employed immigrants report higher weekly earnings than natives even when age and education are controlled for, as shown in Model 1 of Table 7. However, the estimated coefficient, 0.07 , of the immigrant dummy shows that differences in observable characteristics explain about two thirds of the earnings advantage of self-employed immigrants (the observed difference between the two groups is about 21 percent). Model 2 in the same table shows that only the most recent immigrants in 1989 earned less than natives. It also appears that there is no significant difference in weekly earnings across all other arrival cohorts, holding years since migration constant. The higher observed earnings of wage/salary immigrants, compared to natives, can be explained by the variables included in Model 1 of Table 8. In fact, the observed immigrant earnings advantage of about 5 percent turns into an earnings gap favoring natives by approximately 7 percent. The results in Model 2 indicate that the estimated initial earnings upon arrival in the U.S. do not differ between arrival cohorts.

The last two models in Tables 7 and 8 are more flexible than Models 1 and 2 in the sense that they allow for differences in the effect of the included variables for immigrants 
and natives. In addition, they also include controls for national origin groups and occupation. The last model, Model 4, adds a control for self-selection. The results do not appear to be very sensitive to the inclusion of selection correction term. The discussion will therefore focus on the results for Model 4 shown in Tables 7 and 8 .

Immigrants have been found to earn lower returns to schooling than natives (Betts and Lofstrom, 2000). The estimated coefficient on the variable interacting years of schooling with the immigrant indicator variable allows us to test if this also holds for high-skilled immigrants. The estimated coefficients on this variable is negative but statistically insignificant for both self-employed and wage/salary workers. It appears that high-skilled immigrants earn similar returns to education as natives do.

The sign of the coefficient on the inverse Mills ratio variable tells us whether there is an overall positive or negative selection into each sector. Not surprisingly, the correction term indicates that there is positive selection into both wage/salary work and selfemployment. That is, individuals who choose self-employment are better suited for selfemployment, at least in terms of earnings, than are the persons who choose to work in the wage/salary sector and vice versa. However, the coefficient on the correction term for the self-employed is not statistically significant from zero.

The estimated coefficients and correction terms from the earnings equations, Model 4 in tables 7 and 8 , can be used to predict earnings individuals who chose self-employment would have earned if they instead had chosen wage/salary work, and vice versa. This can be done by applying the estimated coefficients from the wage/salary model, for example, to each self-employed individual's observed characteristics and estimated correction term. Predicted average earnings can then be calculated separately for immigrants and 
natives. The exercise gives us insight to "the returns to self-employment". Given that there appears to be positive selection into the wage/salary sector, we expect predicted wage/salary earnings for the self-employed, calculated according to the above described method, to be lower than the predicted self-employment earnings. Indeed, this is what is found. However, the predicted wage/salary earnings do not decrease equally for selfemployed immigrants and natives. The predicted drop for natives is around 11 percent while the decline for immigrants is more than twice that, approximately 25 percent. This indicates that high-skilled immigrants earn higher returns to self-employment than natives. This is somewhat surprising given that we observe lower self-employment rates for high-skilled immigrants than natives. If immigrants earn greater returns to selfemployment than natives, we would expect that they also would be more likely to select self-employment than natives.

One possible explanation for this finding is that there may be constraints, for example capital constraints, that are more binding for immigrant than natives and that this prevent some high-skilled immigrants from becoming entrepreneurs. A finding that is consistent with this conjecture is that the predicted self-employment earnings for wage/salary workers are higher than the predicted wage/salary earnings for immigrants, by 6 percent, and lower for natives, by 6 percent. On average, high-skilled wage/salary immigrants would earn more if they had chosen self-employment.

To address the issue of the rate at which high-skilled immigrants assimilate into the U.S. labor market, and if they are likely to reach earnings parity with high-skilled natives, we want to compare predicted earnings over the work life for immigrants and natives. A convenient way to analyze immigrant labor market assimilation is to compare predicted 
age-earnings profiles for natives and immigrants. Figures 1,2 and 3 show the predicted age-earnings profiles derived from Model 4 in Tables 7 and 8 . It traces out the average predicted log weekly earnings over age by using the estimated coefficients. The notes in the figures show what assumptions are made and which reference groups are used.

Figure 1 shows that high-skilled self-employed immigrants are likely to have higher earnings than statistically similar natives throughout their work life. Wage/salary immigrants are expected to have lower earnings than natives at young ages, but are predicted to reach earnings parity with natives in the wage/salary sector at around age 50 .

It is quite possible that the relative labor market performance varies across country of origin groups. To address this possibility, I derived separate age-earnings profiles for 4 large country of origin groups. Figures 2 and 3 show the predicted earnings for natives and these national origin groups, North East Asia, Mexico, India/Pakistan and Europe/Canada/Australia/New Zealand.

The figures indicate that the variation in earnings across country of origin is less among self-employed immigrants. The results also suggest that within a country of origin group, there are differences in the relative success in the labor market. For example, highskilled self-employed immigrants from Mexico show higher lifetime earnings than their self-employed native counterpart. Mexican immigrants who are working in the wage/salary sector are not predicted to even reach earnings parity with wage/salary natives. It is also well worthwhile to point out that there appears to be no significant difference in the predicted earnings between whites, blacks, Hispanics and Asians. The estimated coefficients in both the wage/salary and the self-employment equations are all within \pm 2 standard errors of each other. 


\section{Summary and Conclusions}

This paper shows, using data from the 1980 and 1990 U.S. Censuses, that a very high proportion of high-skilled workers are self-employed. Approximately one fifth of both high-skilled natives and immigrants are entrepreneurs. The paper also tests for enclave effects on the self-employment probability. Higher proportion of co-nationals and coethnics are found to increase the probability an individual selects self-employment. The relative success of co-nationals and co-ethnics in the self-employment sector is also found to positively affect the self-employment probability.

Immigrants in high-skilled occupations report higher annual earnings than natives. Self-employed natives in high-skill occupations reported 12 percent lower earnings than self-employed immigrants in 1989. The earnings advantage for wage/salary immigrants in that year was about 2 percent. Although both self-employed and wage/salary immigrants are predicted to at least reach earnings parity with natives over their work life, self-employed immigrants are predicted to have higher earnings than self-employed natives throughout most of their work life.

I also find some indications that constraints to enter self-employment, for example capital constraints, may be more binding for high-skilled immigrants than for high-skilled natives.

The variation in earnings across country of origin is less among self-employed immigrants than among wage/salary immigrants. As has been found among the immigrant population overall, the paper also finds that self-employed high-skilled immigrants do relatively better, compared to natives, in the U.S. labor market than 
immigrants working in the wage/salary sector. However, immigrants in both sectors generally do well in the labor market.

Given the findings in this paper, it seems likely that high-skilled immigrants will contribute positively to the U.S. economy. This however assumes that immigrants do not have a negative impact on wages and employment opportunities. Although researchers studying these potential negative effects of immigration generally find no significant effects or only small negative effects (see for example Altonji and Card, 1990 and Borjas, 1994), we do not know if this is also the case for the high-skilled workers. Further research into the possible impact of high-skilled immigration on high-skilled natives' labor market outcomes appears to be warranted. 


\section{References}

Aldrich, Howard E. and Waldinger, Roger. (1990) "Ethnicity and Entrepreneurship." Annual Review of Sociology 16:111-35.

Altonji, Joseph G. and Card, David. (1991) "The Effects of Immigration on the Labor Market Outcomes of Less-Skilled Natives.” In John Abowd and Richard Freeman, eds. Immigration, Trade and the Labor Market, U of Chicago Press.

Betts, Julian R. and Lofstrom, Magnus. (2000) "The Educational Attainment of Immigrants: Trends and Implications." in George J. Borjas (ed) Issues in the Economics of Immigration. University of Chicago Press.

Borjas, George J. (1985) "Assimilation Changes in Cohort Quality and the Earnings of Immigrants.” Journal of Labor Economics, 4:463-89.

Borjas, George J. (1986) "The Self-Employment Experience of Immigrants." Journal of Human Resources 21:485-506.

Borjas, George J. (1994) “The Economics of Immigration.” Journal of Economic Literature 32:1667-717.

Borjas, George J. (1995) “Assimilation Changes in Cohort Quality Revisited: What Happened to Immigrant Earnings in the 1980's?" Journal of Labor Economics 2:201-45.

Bregger, John E. (1996) "Measuring Self-employment in the United States." Monthly Labor Review 3-9.

Camarota, Steven A. (2000) "Reconsidering Immigrant Entrepreneurship: An Examination of Self-Employment Among Natives and the Foreign Born." Washington DC, Center for Immigration Studies.

Carliner, Geoffrey. (1980) "Wages, Earnings and Hours of First, Second, and Third Generation American Males.” Economic Inquiry 1:87-102.

Chiswick, Barry R. (1978) "The Effect of Americanization on the Earnings of Foreignborn Men." Journal of Political Economy 5:897-921.

Cummings, Scott, (1980) Self-Help in Urban America: Patterns of Minority Business Enterprise, Kenikart Press, New York.

Dustmann, C. (1996) "Return Migration: The European Experience" Economic Policy, 22, 213-50. 
Fairlie, Robert W. and Meyer, Bruce D. (1996) "Ethnic and Racial Self-Employment Differences and Possible Explanations." Journal of Human Resources 31:757-93.

Light, Ivan (1984) Immigrant and Ethnic Enterprise in North America. Ethnic and Racial Studies 7:195-216.

Lofstrom, Magnus (1999) "Labor Market Assimilation and the Self-Employment Decision of Immigrant Entrepreneurs.” IZA Discussion Paper No. 54.

Yuengert, Andrew M. (1995) Testing Hypotheses of Immigrant Self-Employment. Journal of Human Resources 30:194-204. 
Table 1

Proportions of Natives and Immigrants in High-Skilled Occupations, Males

Ages 22-64. Data are drawn from

1980 and 1990 Public Use Samples of the U.S. Census. (Number of

Observation in High-Skilled Occupations is 106,908).

\begin{tabular}{|c|c|c|c|c|c|c|}
\hline \multirow[b]{2}{*}{ Occupation: } & \multicolumn{2}{|c|}{1980} & \multicolumn{2}{|c|}{1990} & \multicolumn{2}{|c|}{$\begin{array}{c}\text { Change } \\
1980-1990\end{array}$} \\
\hline & Natives & Immigrants & Natives & Immigrants & Natives & Immigrants \\
\hline \multirow[t]{2}{*}{ High-Skilled Overall } & $7.3 \%$ & $9.7 \%$ & $8.5 \%$ & $9.2 \%$ & $1.2 \%$ & $-0.5 \%$ \\
\hline & \multicolumn{6}{|c|}{ Distribution of High-Skilled Occupations } \\
\hline Management and Finance & $23.0 \%$ & $16.2 \%$ & $24.5 \%$ & $18.7 \%$ & $1.5 \%$ & $2.5 \%$ \\
\hline Architecture & $2.4 \%$ & $2.9 \%$ & $2.4 \%$ & $3.0 \%$ & $0.0 \%$ & $0.1 \%$ \\
\hline Engineering & $32.5 \%$ & $37.8 \%$ & $28.5 \%$ & $34.8 \%$ & $-4.0 \%$ & $-3.0 \%$ \\
\hline Computer Sciences & $5.6 \%$ & $4.1 \%$ & $8.6 \%$ & $9.1 \%$ & $3.0 \%$ & $5.0 \%$ \\
\hline Mathematical and Natural Sciences & $6.5 \%$ & $7.3 \%$ & $6.0 \%$ & $6.9 \%$ & $-0.5 \%$ & $-0.4 \%$ \\
\hline Health and Medicine & $15.8 \%$ & $25.9 \%$ & $15.0 \%$ & $21.7 \%$ & $-0.8 \%$ & $-4.2 \%$ \\
\hline Social Sciences & $3.4 \%$ & $2.8 \%$ & $3.5 \%$ & $2.6 \%$ & $0.1 \%$ & $-0.2 \%$ \\
\hline Law & $10.9 \%$ & $3.0 \%$ & $11.6 \%$ & $3.2 \%$ & $0.7 \%$ & $0.2 \%$ \\
\hline
\end{tabular}




\section{Table 2}

Self-Employment Rates by High-Skilled Occupations, Males Ages 22-64. Data are drawn from 1980 and 1990Public Use Samples of the U.S. Census.

\begin{tabular}{lcccccc}
\hline & \multicolumn{2}{c}{1980} & \multicolumn{2}{c}{1990} & \multicolumn{2}{c}{$\begin{array}{c}\text { Change } \\
1980-1990\end{array}$} \\
Occupation: & \multicolumn{2}{c}{ Natives Immigrants } & Natives & Immigrants & Natives Immigrants \\
\hline \hline & $12.8 \%$ & $12.5 \%$ & $12.9 \%$ & $13.0 \%$ & $0.1 \%$ & $0.5 \%$ \\
All Occupations & & & & & & \\
& $12.1 \%$ & $11.9 \%$ & $12.2 \%$ & $12.5 \%$ & $0.1 \%$ & $0.6 \%$ \\
Less-Skilled Overall & $21.0 \%$ & $18.6 \%$ & $20.7 \%$ & $18.4 \%$ & $-0.3 \%$ & $-0.2 \%$ \\
High-Skilled Overall & & & & & & \\
& $14.9 \%$ & $11.5 \%$ & $18.3 \%$ & $17.6 \%$ & $3.4 \%$ & $6.1 \%$ \\
Management and Finance & $43.6 \%$ & $32.0 \%$ & $34.7 \%$ & $31.3 \%$ & $-8.9 \%$ & $-0.7 \%$ \\
Architecture & $3.0 \%$ & $3.0 \%$ & $3.6 \%$ & $3.6 \%$ & $0.6 \%$ & $0.6 \%$ \\
Engineering & $3.2 \%$ & $2.8 \%$ & $6.2 \%$ & $5.8 \%$ & $3.0 \%$ & $3.0 \%$ \\
Computer Sciences & $4.5 \%$ & $3.4 \%$ & $5.7 \%$ & $3.7 \%$ & $1.2 \%$ & $0.3 \%$ \\
Mathematical and Natural Sciences & $57.4 \%$ & $48.4 \%$ & $50.6 \%$ & $48.0 \%$ & $-6.8 \%$ & $-0.4 \%$ \\
Health and Medicine & $10.0 \%$ & $11.2 \%$ & $19.4 \%$ & $14.2 \%$ & $9.4 \%$ & $3.0 \%$ \\
Social Sciences & $52.3 \%$ & $49.7 \%$ & $45.3 \%$ & $42.5 \%$ & $-7.0 \%$ & $-7.2 \%$ \\
\hline Law & & & & &
\end{tabular}


Table 3

Self-Employment Rates and Proportions of Immigrants in High-Skilled Occupations by National Origin Groups, Males Ages 22-64. Data are drawn from 1980 and 1990 Public Use Samples of the U.S. Census.

\begin{tabular}{|c|c|c|c|c|c|c|c|c|}
\hline \multirow{2}{*}{ National Origin Group: } & \multicolumn{5}{|c|}{ Proportion (and Sample Size) in High Skill Occupations } & \multicolumn{3}{|c|}{ Self-Employment Rates } \\
\hline & \multicolumn{2}{|c|}{1980} & \multicolumn{2}{|c|}{1990} & $\begin{array}{c}\text { Change } \\
1980-1990 \\
\end{array}$ & 1980 & 1990 & Change \\
\hline Mexico & $1.0 \%$ & $(279)$ & $0.9 \%$ & $(492)$ & $-0.1 \%$ & $24.4 \%$ & $19.5 \%$ & $-4.9 \%$ \\
\hline Central/South America & $7.0 \%$ & $(779)$ & $5.3 \%$ & $(1,385)$ & $-1.7 \%$ & $19.6 \%$ & $20.6 \%$ & $1.0 \%$ \\
\hline South East Asia & $15.3 \%$ & $(1,357)$ & $12.6 \%$ & $(2,496)$ & $-2.7 \%$ & $20.9 \%$ & $14.6 \%$ & $-6.3 \%$ \\
\hline North East Asia & $19.0 \%$ & $(1,941)$ & $16.9 \%$ & $(3,296)$ & $-2.1 \%$ & $13.8 \%$ & $14.7 \%$ & $0.9 \%$ \\
\hline India, Pakistan & $42.9 \%$ & $(1,953)$ & $31.4 \%$ & $(2,921)$ & $-11.5 \%$ & $13.5 \%$ & $18.9 \%$ & $5.4 \%$ \\
\hline Middle East/Egypt & $17.8 \%$ & $(776)$ & $19.0 \%$ & $(1,933)$ & $1.2 \%$ & $23.1 \%$ & $20.6 \%$ & $-2.5 \%$ \\
\hline Europe,CAN,AUS,NZ & $9.6 \%$ & $(5,877)$ & $11.8 \%$ & $(6,201)$ & $2.2 \%$ & $19.1 \%$ & $20.0 \%$ & $0.9 \%$ \\
\hline Africa & $18.0 \%$ & $(311)$ & $16.5 \%$ & $(673)$ & $-1.5 \%$ & $17.4 \%$ & $13.7 \%$ & $-3.7 \%$ \\
\hline Caribbean & $5.1 \%$ & $(389)$ & $4.7 \%$ & $(550)$ & $-0.4 \%$ & $15.7 \%$ & $16.2 \%$ & $0.5 \%$ \\
\hline Cuba & $7.7 \%$ & $(648)$ & $7.5 \%$ & $(763)$ & $-0.2 \%$ & $29.3 \%$ & $30.4 \%$ & $1.1 \%$ \\
\hline Other & $8.3 \%$ & $(801)$ & $5.5 \%$ & $(507)$ & $-2.8 \%$ & $21.3 \%$ & $15.0 \%$ & $-6.3 \%$ \\
\hline
\end{tabular}


Table 4

Total Annual Income (in \$1989) and Ratio of Average Total Annual Income, Natives/Immigrants, by High-Skilled Occupations, Males Ages 22-64. Data are drawn from 1980 and 1990 Public Use Samples of the U.S. Census.

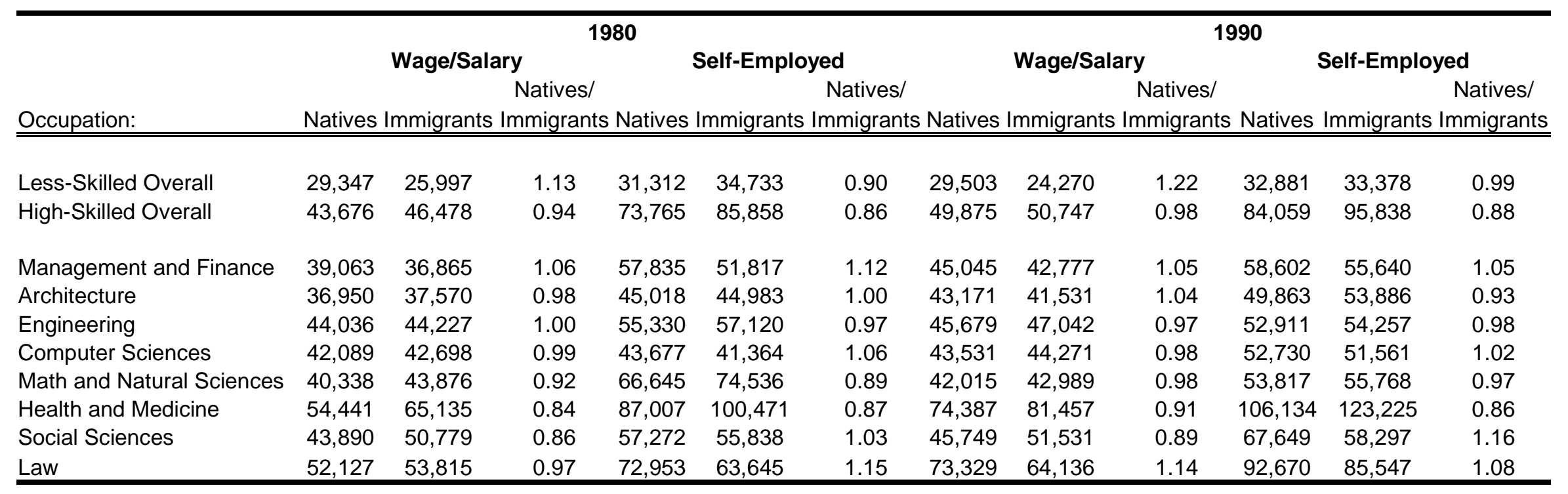


Table 5

Mean Characteristics for Natives and Immigrants in High-Skilled Occupations, Males Ages 22-64. Data are drawn from 1980 and 1990 Public Use Samples of the U.S. Census.

\begin{tabular}{lcc}
\hline & Natives & Immigrants \\
Variable: & & \\
\hline \hline & 0.208 & 0.185 \\
Self-Employed & 49.52 & 48.90 \\
Weeks Worked & 44.60 & 44.88 \\
Hours per Week & 6.74 & 6.80 \\
Log Weekly Wage & 39.49 & 40.04 \\
Age & 16.59 & 17.32 \\
Years of Schooling & 0.234 & 0.301 \\
Northeast & 0.234 & 0.167 \\
Midwest & 0.222 & 0.301 \\
West & 0.034 & 0.015 \\
Disability & 0.763 & 0.799 \\
Married & 0.899 & 0.968 \\
SMSA Resident & 0.447 & 0.389 \\
Period Effect 1980 & $\mathrm{N} / \mathrm{A}$ & 17.33 \\
Years Since Migration & $\mathrm{N} / \mathrm{A}$ & 0.021 \\
Limited English Proficiency & 0.767 & $\mathrm{~N} / \mathrm{A}$ \\
Proportion of Natives of the Same & & \\
Ethnicity in SMSA & 0.659 & $\mathrm{~N} / \mathrm{A}$ \\
Ratio of S-E earnings to W/S earnings & & \\
by SMSA and Ethnicity & $\mathrm{N} / \mathrm{A}$ & 0.010 \\
Proportion of Immigrants from Same & & \\
Country of Origin Group in SMSA & $\mathrm{N} / \mathrm{A}$ & 0.703 \\
Ratio of S-E earnings to W/S earnings & & \\
by SMSA and National Origin Group & & \\
& & \\
Number of Observations & & \\
\hline
\end{tabular}




\section{Table 6}

\section{Probit Models of Self-Employment for High-Skilled Males Ages 22-64.}

Note: The table shows marginal effects and robust standard errors in parentheses. Data are drawn from 1980 and 1990 Public Use Samples of the U.S. Census.

\begin{tabular}{|c|c|c|c|c|}
\hline Variable: & Model 1 & Model 2 & Model 3 & Model 4 \\
\hline Immigrant & $\begin{array}{l}-0.0569 \\
(0.0023)\end{array}$ & $\begin{array}{l}-0.1288 \\
(0.0057)\end{array}$ & $\begin{array}{c}0.2876 \\
(0.1006)\end{array}$ & $\begin{array}{c}0.2044 \\
(0.0947)\end{array}$ \\
\hline Age & $\begin{array}{c}0.0300 \\
(0.0011)\end{array}$ & $\begin{array}{c}0.0300 \\
(0.0011)\end{array}$ & $\begin{array}{c}0.0335 \\
(0.0017)\end{array}$ & $\begin{array}{c}0.0318 \\
(0.0016)\end{array}$ \\
\hline Age2/100 & $\begin{array}{l}-0.0263 \\
(0.0013)\end{array}$ & $\begin{array}{l}-0.0264 \\
(0.0013)\end{array}$ & $\begin{array}{l}-0.0300 \\
(0.0019)\end{array}$ & $\begin{array}{l}-0.0289 \\
(0.0018)\end{array}$ \\
\hline Years of Schooling & $\begin{array}{c}0.0530 \\
(0.0006)\end{array}$ & $\begin{array}{c}0.0530 \\
(0.0006)\end{array}$ & $\begin{array}{c}0.0519 \\
(0.0009)\end{array}$ & $\begin{array}{c}0.0091 \\
(0.0009)\end{array}$ \\
\hline Northeast & $\begin{array}{l}-0.0067 \\
(0.0036)\end{array}$ & $\begin{array}{l}-0.0068 \\
(0.0036)\end{array}$ & $\begin{array}{c}0.0049 \\
(0.0055)\end{array}$ & $\begin{array}{c}0.0014 \\
(0.0050)\end{array}$ \\
\hline Midwest & $\begin{array}{l}-0.0065 \\
(0.0038)\end{array}$ & $\begin{array}{l}-0.0067 \\
(0.0038)\end{array}$ & $\begin{array}{l}-0.0032 \\
(0.0057)\end{array}$ & $\begin{array}{l}-0.0083 \\
(0.0052)\end{array}$ \\
\hline West & $\begin{array}{c}0.0070 \\
(0.0038)\end{array}$ & $\begin{array}{c}0.0068 \\
(0.0038)\end{array}$ & $\begin{array}{c}0.0077 \\
(0.0056)\end{array}$ & $\begin{array}{c}0.0173 \\
(0.0054)\end{array}$ \\
\hline Disability & $\begin{array}{c}0.0206 \\
(0.0084)\end{array}$ & $\begin{array}{c}0.0205 \\
(0.0084)\end{array}$ & $\begin{array}{c}0.0330 \\
(0.0130)\end{array}$ & $\begin{array}{c}0.0241 \\
(0.0118)\end{array}$ \\
\hline Married & $\begin{array}{c}0.0188 \\
(0.0036)\end{array}$ & $\begin{array}{c}0.0191 \\
(0.0035)\end{array}$ & $\begin{array}{c}0.0160 \\
(0.0051)\end{array}$ & $\begin{array}{c}0.0158 \\
(0.0047)\end{array}$ \\
\hline SMSA Resident & $\begin{array}{c}-0.0684 \\
(0.0053)\end{array}$ & $\begin{array}{l}-0.0682 \\
(0.0053)\end{array}$ & $\begin{array}{l}-0.0685 \\
(0.0079)\end{array}$ & $\begin{array}{l}-0.0389 \\
(0.0072)\end{array}$ \\
\hline Period Effect 1980 & $\begin{array}{c}0.0114 \\
(0.0027)\end{array}$ & $\begin{array}{c}0.0134 \\
(0.0029)\end{array}$ & $\begin{array}{c}0.0691 \\
(0.0574)\end{array}$ & $\begin{array}{l}-0.1226 \\
(0.0479)\end{array}$ \\
\hline Years Since Migration & & $\begin{array}{c}0.0064 \\
(0.0010)\end{array}$ & $\begin{array}{c}0.0071 \\
(0.0011)\end{array}$ & $\begin{array}{c}0.0086 \\
(0.0010)\end{array}$ \\
\hline Years Since Migration2/100 & & $\begin{array}{l}-0.0030 \\
(0.0022)\end{array}$ & $\begin{array}{l}-0.0047 \\
(0.0022)\end{array}$ & $\begin{array}{l}-0.0086 \\
(0.0020)\end{array}$ \\
\hline Arrival Cohort Pre-1950 & & $\begin{array}{l}-0.0510 \\
(0.0212)\end{array}$ & $\begin{array}{l}-0.0410 \\
(0.0238)\end{array}$ & $\begin{array}{c}-0.0596 \\
(0.0168)\end{array}$ \\
\hline Arrival Cohort 1950-59 & & $\begin{array}{l}-0.0132 \\
(0.0196)\end{array}$ & $\begin{array}{l}-0.0155 \\
(0.0206)\end{array}$ & $\begin{array}{l}-0.0445 \\
(0.0149)\end{array}$ \\
\hline Arrival Cohort 1960-64 & & $\begin{array}{c}0.0003 \\
(0.0188)\end{array}$ & $\begin{array}{l}-0.0051 \\
(0.0192)\end{array}$ & $\begin{array}{l}-0.0332 \\
(0.0146)\end{array}$ \\
\hline Arrival Cohort 1965-69 & & $\begin{array}{c}0.0004 \\
(0.0169)\end{array}$ & $\begin{array}{c}0.0126 \\
(0.0182)\end{array}$ & $\begin{array}{l}-0.0127 \\
(0.0149)\end{array}$ \\
\hline Arrival Cohort 1970-74 & & $\begin{array}{c}0.0340 \\
(0.0170)\end{array}$ & $\begin{array}{c}0.0580 \\
(0.0185)\end{array}$ & $\begin{array}{c}0.0029 \\
(0.0144)\end{array}$ \\
\hline Arrival Cohort 1975-79 & & $\begin{array}{c}0.0408 \\
(0.0158)\end{array}$ & $\begin{array}{c}0.0479 \\
(0.0159)\end{array}$ & $\begin{array}{c}0.0106 \\
(0.0133)\end{array}$ \\
\hline Arrival Cohort 1980-84 & & $\begin{array}{c}0.0456 \\
(0.0174)\end{array}$ & $\begin{array}{c}0.0547 \\
(0.0174)\end{array}$ & $\begin{array}{c}0.0253 \\
(0.0154)\end{array}$ \\
\hline
\end{tabular}

Continued... 
Continued:

Limited English Proficiency

Proportion of Immigrants from Same

Country of Origin Group in SMSA

Proportion of Natives of the Same

Ethnicity in SMSA

Ratio of S-E earnings to W/S earnings

by SMSA and National Origin Group

Ratio of S-E earnings to W/S earnings

by SMSA and Ethnicity

Model Interacted with Immigrants and

Census Year

Model Includes Controls for Country of

Origin and Ethnicity

Model Includes Controls for Occupation

Number of Observations

Log Likelihood
0.0915

$(0.0248)$

$-0.0109$

(0.0016)

0.1901

$(0.0690)$

0.0206

$(0.0123)$

0.0329

$(0.0124)$

0.0579

(0.0112)

0.0480

(0.0204)

$-0.0049$

$(0.0011)$

0.0926

(0.0507)

0.0318

$(0.0113)$

0.0213

(0.0086)

0.0412

(0.0099)

$\begin{array}{llll}\text { No } & \text { No } & \text { Yes } & \text { Yes } \\ \text { No } & \text { No } & \text { Yes } & \text { Yes } \\ \text { No } & \text { No } & \text { No } & \text { Yes }\end{array}$

106,908

106,908

105,545

105,545

$-45,364$

$-45,310$ 


\section{Table 7}

\section{Linear Earnings Models of Log Weekly Total Earnings, Self-Emploved}

\section{High-Skilled Males Ages 22-64.}

Note: The table shows robust standard errors in parentheses. Data are drawn from 1980 and 1990 Public Use Samples of the U.S. Census.

\begin{tabular}{|c|c|c|c|c|}
\hline Variable & Model 1 & Model 2 & Model 3 & Model 4 \\
\hline Constant & $\begin{array}{r}1.7401 \\
(0.1422)\end{array}$ & $\begin{array}{r}1.7665 \\
(0.1429)\end{array}$ & $\begin{array}{r}2.0256 \\
(0.2396)\end{array}$ & $\begin{array}{r}1.9339 \\
(0.2433)\end{array}$ \\
\hline Immigrant & $\begin{array}{r}0.0662 \\
(0.0138)\end{array}$ & $\begin{array}{r}-0.2938 \\
(0.0816)\end{array}$ & $\begin{array}{r}-0.1625 \\
(0.3123)\end{array}$ & $\begin{array}{r}-0.1561 \\
(0.3123)\end{array}$ \\
\hline Age & $\begin{array}{r}0.1243 \\
(0.0064)\end{array}$ & $\begin{array}{r}0.1236 \\
(0.0072)\end{array}$ & $\begin{array}{r}0.1204 \\
(0.0102)\end{array}$ & $\begin{array}{r}0.1229 \\
(0.0114)\end{array}$ \\
\hline Age2/100 & $\begin{array}{r}-0.1319 \\
(0.0072)\end{array}$ & $\begin{array}{r}-0.1311 \\
(0.0072)\end{array}$ & $\begin{array}{r}-0.1285 \\
(0.0113)\end{array}$ & $\begin{array}{r}-0.1308 \\
(0.0114)\end{array}$ \\
\hline Years of Schooling & $\begin{array}{r}0.1185 \\
(0.0033)\end{array}$ & $\begin{array}{r}0.1180 \\
(0.0033)\end{array}$ & $\begin{array}{r}0.0925 \\
(0.0060)\end{array}$ & $\begin{array}{r}0.0932 \\
(0.0060)\end{array}$ \\
\hline Northeast & $\begin{array}{r}0.0361 \\
(0.0182)\end{array}$ & $\begin{array}{r}0.0368 \\
(0.0182)\end{array}$ & $\begin{array}{r}0.0459 \\
(0.0279)\end{array}$ & $\begin{array}{r}0.0463 \\
(0.0279)\end{array}$ \\
\hline Midwest & $\begin{array}{r}0.0035 \\
(0.0189)\end{array}$ & $\begin{array}{r}0.0031 \\
(0.0189)\end{array}$ & $\begin{array}{r}-0.0697 \\
(0.0288)\end{array}$ & $\begin{array}{r}-0.0702 \\
(0.0288)\end{array}$ \\
\hline West & $\begin{array}{r}0.0042 \\
(0.0188)\end{array}$ & $\begin{array}{r}0.0053 \\
(0.0188)\end{array}$ & $\begin{array}{r}-0.0076 \\
(0.0283)\end{array}$ & $\begin{array}{r}-0.0059 \\
(0.0282)\end{array}$ \\
\hline Disability & $\begin{array}{r}-0.3208 \\
(0.0468)\end{array}$ & $\begin{array}{r}-0.3208 \\
(0.0469)\end{array}$ & $\begin{array}{r}-0.3582 \\
(0.0721)\end{array}$ & $\begin{array}{r}-0.3567 \\
(0.0720)\end{array}$ \\
\hline Married & $\begin{array}{r}0.2964 \\
(0.0212)\end{array}$ & $\begin{array}{r}0.2960 \\
(0.0212)\end{array}$ & $\begin{array}{r}0.2865 \\
(0.0309)\end{array}$ & $\begin{array}{r}0.2883 \\
(0.0308)\end{array}$ \\
\hline SMSA Resident & $\begin{array}{r}0.1341 \\
(0.0209)\end{array}$ & $\begin{array}{r}0.1346 \\
(0.0209)\end{array}$ & $\begin{array}{r}0.1861 \\
(0.0305)\end{array}$ & $\begin{array}{r}0.1834 \\
(0.0305)\end{array}$ \\
\hline Period Effect 1980 & $\begin{array}{r}-0.0307 \\
(0.0133)\end{array}$ & $\begin{array}{r}-0.0319 \\
(0.0143)\end{array}$ & $\begin{array}{r}0.0514 \\
(0.2857)\end{array}$ & $\begin{array}{r}0.0402 \\
(0.2859)\end{array}$ \\
\hline Limited English Proficiency & & $\begin{array}{r}-0.3387 \\
(0.1136)\end{array}$ & $\begin{array}{r}-0.3403 \\
(0.1064)\end{array}$ & $\begin{array}{r}-0.3397 \\
(0.1061)\end{array}$ \\
\hline Years of Schooling*Immigrant & & & $\begin{array}{r}-0.0083 \\
(0.0066)\end{array}$ & $\begin{array}{r}-0.0090 \\
(0.0066)\end{array}$ \\
\hline Years Since Migration & & $\begin{array}{r}0.0024 \\
(0.0052)\end{array}$ & $\begin{array}{r}0.0042 \\
(0.0052)\end{array}$ & $\begin{array}{r}0.0041 \\
(0.0052)\end{array}$ \\
\hline Years Since Migration2/100 & & $\begin{array}{r}-0.0024 \\
(0.0101)\end{array}$ & $\begin{array}{r}-0.0034 \\
(0.0102)\end{array}$ & $\begin{array}{r}-0.0040 \\
(0.0103)\end{array}$ \\
\hline Arrival Cohort Pre-1950 & & $\begin{array}{r}0.2906 \\
(0.1441)\end{array}$ & $\begin{array}{r}0.2778 \\
(0.1424)\end{array}$ & $\begin{array}{r}0.3026 \\
(0.1425)\end{array}$ \\
\hline Arrival Cohort 1950-59 & & $\begin{array}{r}0.3020 \\
(0.1189)\end{array}$ & $\begin{array}{r}0.2753 \\
(0.1167)\end{array}$ & $\begin{array}{r}0.2922 \\
(0.1167)\end{array}$ \\
\hline Arrival Cohort 1960-64 & & $\begin{array}{r}0.3451 \\
(0.1101)\end{array}$ & $\begin{array}{r}0.3344 \\
(0.1084) \\
\end{array}$ & $\begin{array}{r}0.3460 \\
(0.1084) \\
\end{array}$ \\
\hline
\end{tabular}

Continued... 
Continued:

Arrival Cohort 1965-69

$\begin{array}{lll}0.3801 & 0.3360 & 0.3480\end{array}$

$\begin{array}{lll}(0.1018) & (0.0994) \quad(0.0993)\end{array}$

Arrival Cohort 1970-74

$\begin{array}{lll}0.3762 & 0.2995 & 0.3044\end{array}$

$\begin{array}{lll}(0.0949) & (0.0936) & (0.0936)\end{array}$

Arrival Cohort 1975-79

0.3644

0.3104

0.3157

(0.0903)

(0.0880)

$(0.0880)$

Arrival Cohort 1980-84

0.2653

0.2277

0.2328

(0.0967)

(0.0936)

$(0.0936)$

Correction Term

0226

$(0.0152)$

Model Interacted with Immigrants and

Census Year

Model Includes Controls for Country of

Origin, Ethnicity and Occupation

Model Controls for Self- Selection

No

No

Yes

Yes

No

No

Yes

Yes

No

No

No

Yes

Number of Observations

21,663

21,663

21,663

21,598

R-squared 


\section{Table 8 \\ Linear Earnings Models of Log Weekly Total Earnings, Wage/Salary High-Skilled Males Ages 22-64.}

Note: The table shows robust standard errors in parentheses. Data are drawn from 1980 and 1990 Public Use Samples of the U.S. Census.

\begin{tabular}{|c|c|c|c|c|}
\hline Variable & Model 1 & Model 2 & Model 3 & Model 4 \\
\hline \multirow[t]{2}{*}{ Constant } & 3.3657 & 3.3703 & 3.0306 & 3.0457 \\
\hline & $(0.0353)$ & $(0.0354)$ & (0.0569) & $(0.0571)$ \\
\hline \multirow[t]{2}{*}{ Immigrant } & -0.0716 & -0.2181 & 0.0691 & 0.0890 \\
\hline & $(0.0043)$ & $(0.0146)$ & $(0.0774)$ & $(0.0785)$ \\
\hline \multirow[t]{2}{*}{ Age } & 0.0901 & 0.0900 & 0.0930 & 0.0915 \\
\hline & $(0.0017)$ & $(0.0021)$ & $(0.0025)$ & $(0.0032)$ \\
\hline \multirow[t]{2}{*}{ Age2/100 } & -0.0902 & -0.0905 & -0.0940 & -0.0928 \\
\hline & $(0.0021)$ & $(0.0021)$ & $(0.0032)$ & $(0.0032)$ \\
\hline \multirow[t]{2}{*}{ Years of Schooling } & 0.0660 & 0.0661 & 0.0749 & 0.0745 \\
\hline & $(0.0010)$ & $(0.0010)$ & $(0.0017)$ & $(0.0017)$ \\
\hline \multirow[t]{2}{*}{ Northeast } & 0.0619 & 0.0617 & 0.1010 & 0.1009 \\
\hline & $(0.0055)$ & $(0.0055)$ & $(0.0082)$ & $(0.0083)$ \\
\hline \multirow[t]{2}{*}{ Midwest } & 0.0115 & 0.0111 & -0.0103 & -0.0099 \\
\hline & $(0.0057)$ & $(0.0057)$ & $(0.0086)$ & $(0.0086)$ \\
\hline \multirow{2}{*}{ West } & 0.0316 & 0.0315 & 0.0413 & 0.0398 \\
\hline & $(0.0057)$ & $(0.0057)$ & $(0.0082)$ & $(0.0083)$ \\
\hline \multirow[t]{2}{*}{ Disability } & -0.1552 & -0.1549 & -0.1822 & -0.1827 \\
\hline & $(0.0163)$ & $(0.0163)$ & (0.0258) & (0.0259) \\
\hline \multirow[t]{2}{*}{ Married } & 0.1205 & 0.1214 & 0.1229 & 0.1217 \\
\hline & $(0.0052)$ & $(0.0052)$ & (0.0075) & (0.0075) \\
\hline \multirow[t]{2}{*}{ SMSA Resident } & 0.1447 & 0.1449 & 0.1606 & 0.1642 \\
\hline & $(0.0077)$ & $(0.0077)$ & $(0.0110)$ & $(0.0110)$ \\
\hline \multirow[t]{2}{*}{ Period Effect 1980} & -0.0635 & -0.0619 & 0.4590 & 0.4622 \\
\hline & $(0.0041)$ & $(0.0044)$ & $(0.0682)$ & $(0.0684)$ \\
\hline \multirow[t]{2}{*}{ Limited English Proficiency } & & -0.1613 & -0.1521 & -0.1592 \\
\hline & & $(0.0340)$ & $(0.0340)$ & $(0.0349)$ \\
\hline \multirow[t]{2}{*}{ Years of Schooling ${ }^{\star} I m m i g r a n t$} & & & -0.0020 & -0.0018 \\
\hline & & & $(0.0021)$ & $(0.0021)$ \\
\hline \multirow[t]{2}{*}{ Years Since Migration } & & 0.0144 & 0.0132 & 0.0132 \\
\hline & & $(0.0015)$ & $(0.0016)$ & $(0.0016)$ \\
\hline \multirow[t]{2}{*}{ Years Since Migration2/100 } & & -0.0158 & -0.0171 & -0.0169 \\
\hline & & $(0.0035)$ & (0.0036) & $(0.0036)$ \\
\hline \multirow[t]{2}{*}{ Arrival Cohort Pre-1950 } & & -0.0646 & 0.0129 & 0.0051 \\
\hline & & $(0.0407)$ & $(0.0430)$ & $(0.0436)$ \\
\hline \multirow[t]{2}{*}{ Arrival Cohort 1950-59 } & & -0.0509 & -0.0046 & -0.0071 \\
\hline & & $(0.0293)$ & $(0.0304)$ & (0.0309) \\
\hline \multirow[t]{2}{*}{ Arrival Cohort 1960-64 } & & -0.0300 & 0.0535 & 0.0521 \\
\hline & & $(0.0263)$ & $(0.0270)$ & $(0.0275)$ \\
\hline
\end{tabular}

Continued... 
Continued:

Arrival Cohort 1965-69

Correction Term

Model Interacted with Immigrants and

Census Year

Model Includes Controls for Country of

Origin, Ethnicity and Occupation

Model Controls for Self- Selection

Number of Observations

R-squared
$-0.0266$

$(0.0233)$

0.0114

$(0.0203)$

0.0134

$(0.0182)$

$-0.0131$

$(0.0192)$

$\begin{array}{rr}0.0480 & 0.0440 \\ (0.0238) & (0.0243) \\ 0.0832 & 0.0796 \\ (0.0206) & (0.0210) \\ 0.0481 & 0.0455 \\ (0.0182) & (0.0185) \\ 0.0116 & 0.0102 \\ (0.0189) & (0.0192) \\ & -0.0440 \\ & (0.0029)\end{array}$

No

No

Yes

Yes

No

No

Yes

Yes

No

No

No

Yes

$84,965 \quad 84,965 \quad 84,965 \quad 83,688$

$\begin{array}{llll}0.2319 & 0.2339 & 0.2550 & 0.2551\end{array}$


Table A1.

Definition of National Origin Groups.

Mexico:

Mexico

South and Central America:

Argentina, Bolivia, Brazil, Chile, Colombia, Ecuador, Falkland Islands, French Guyana, Guyana, Paraguay, Peru, Suriname, Uruguay, Venezuela, Belize, Costa Rica, El Salvador, Guatemala, Honduras, Nicaragua, Panama.

\section{South East Asia:}

Bangladesh, Brunei, Burma, Cambodia, Indonesia, Laos, Macau, Malaysia, Philippines, Thailand, Vietnam.

\section{North East Asia:}

China, Hong Kong, Japan, North Korea, Singapore, South Korea, Taiwan.

India/Pakistan:

Bangladesh, Bhutan, India, Nepal, Pakistan, Sri Lanka.

Middle East/Egypt:

Bahrain, Cyprus, Iran, Iraq, Israel, Jordan, Kuwait, Lebanon, Oman, Qatar, Saudi Arabia, Syria, Turkey, United Arab Emirates, Yemen, Egypt.

Europe, Canada, Australia, New Zealand:

Albania, Andorra, Austria, Belgium, Bulgaria, Czechoslovakia, Denmark, Faeroe Islands, Finland, France, Germany, Gibraltar, Greece, Hungary, Iceland, Ireland, Italy, Liechtenstein, Luxembourg, Malta, Monaco, Netherlands, Norway, Poland, Portugal, Romania, San Marino, Spain, Sweden, Switzerland, United Kingdom, Vatican, Yugoslavia, Soviet Union, Canada, Australia, New Zealand.

\section{Caribbean:}

Anguilla, Antigua and Barbuda, Aruba, Bahamas, Barbados, British Virgin Islands, Cayman Islands, Dominica, Dominican Republic, Grenada, Guadeloupe, Haiti, Jamaica, Martinique, Montserrat, Netherlands Antilles, St. Barthelemy, St.Kitts-Nevis, St. Lucia, St. Vincent and the Grenadines, Trinidad and Tobago, Turks and Caicos Islands.

Cuba:

Cuba

Africa:

Algeria, Angola, Benin, Botswana, British Indian Ocean Territory, Burkina Faso, Burundi, Cameroon, Cape Verde, Central African Republic, Chad, Comoros, Congo, Djibouti, Equatorial Guinea, Ethiopia, Gabon, Gambia, Ghana, Glorioso Islands, Guinea, Guinea-Bissau, Ivory Coast, Juan de Nova Island, Kenya, Lesotho, Liberia, Libya, Madagascar, Malawi, Mali, Mauritania, Mayotte, Morocco, Mozambique, Namibia, Niger, Nigeria, Reunion, Rwanda, Sao Tome and Principe, Senegal, Mauritius, Seychelles, Sierra Leone, Somalia, South Africa, St. Helena, Sudan, Swaziland, Tanzania, Togo, Tromelin Island, Tunisia, Uganda, Western Sahara, Zaire, Zambia, Zimbabwe. 


\section{Figure 1.}

Predicted Age-Earnings Profile for Self-Employed and Wage/Salary Immigrants and Natives.

Note: The age-earnings profiles are derived from the estimated Models 4 in Tables 7 and 8 . Individuals are assumed to be married, have 18 years of schooling and are residing in a SMSA. Furthermore, the estimates for North East Asian immigrants who arrived between 1975 and 1979 are used.

Baseline is 1990 .

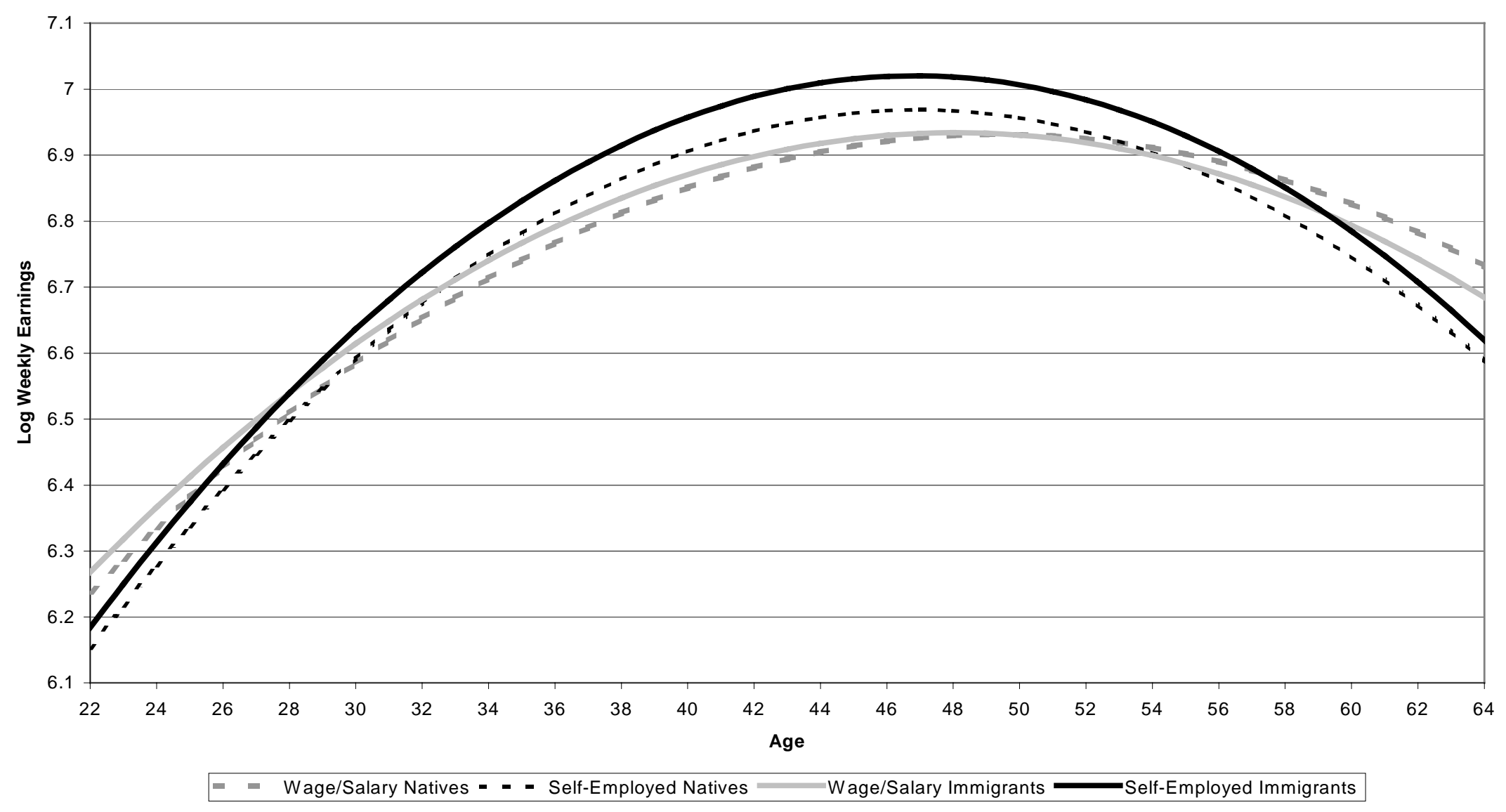


Figure 2.

\section{Predicted Age-Earnings Profile for Self-Employed Immigrants and Natives by Country of Origin group.}

Note: The age-earnings profiles are derived from the estimated Model 4 in Table 7. Individuals are assumed to be married, have 18 years of schooling and are residing in a SMSA. Furthermore, the estimates for who arrived between 1975 and 1979 are used. Baseline is 1990.

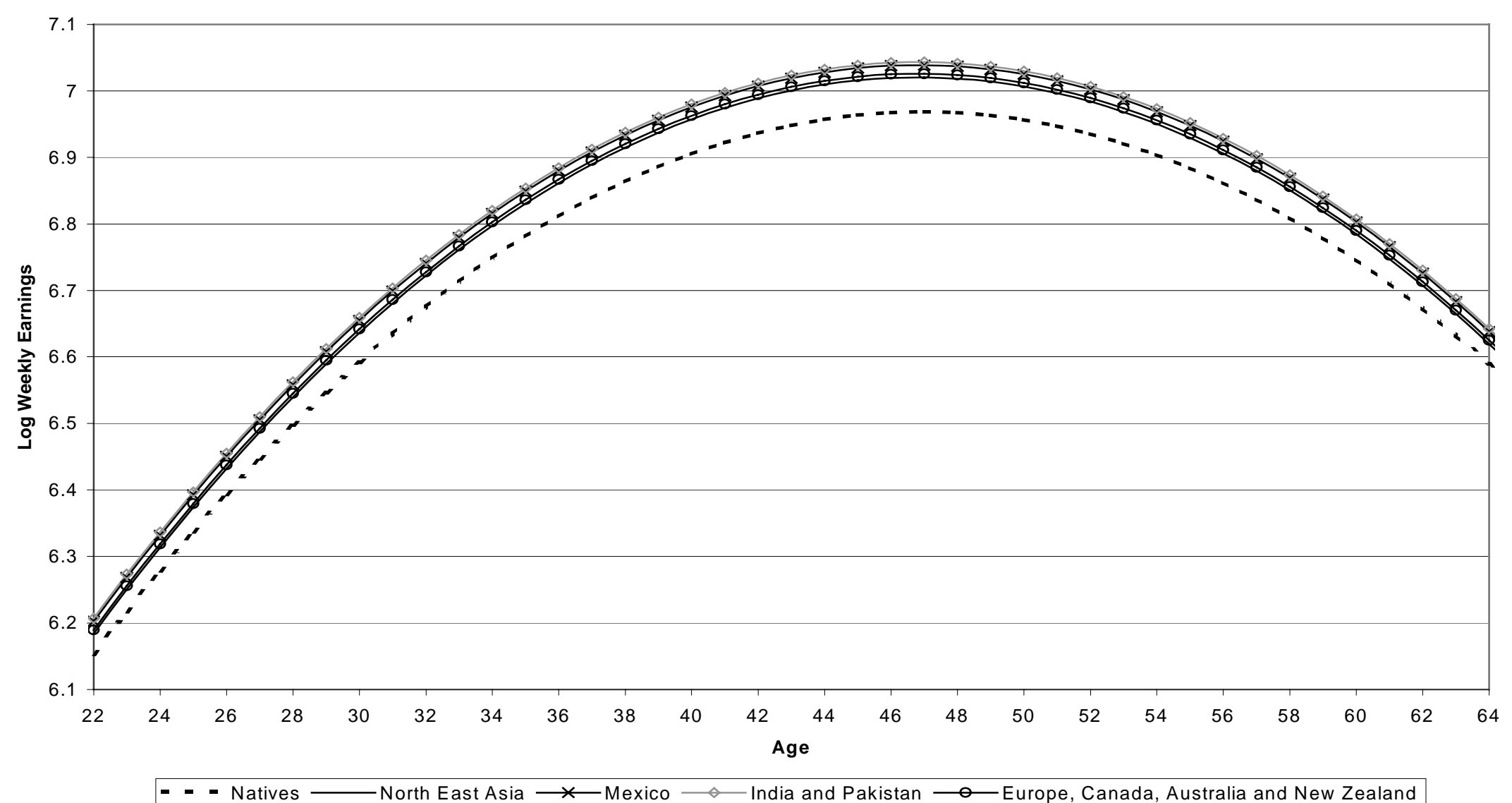


Figure 3.

Predicted Age-Earnings Profile for Wage/Salary Immigrants and Natives by Country of Origin group.

Note: The age-earnings profiles are derived from the estimated Model 4 in Table 8 . Individuals are assumed to be married, have 18 years of schooling and are residing in a SMSA. Furthermore, the estimates for who arrived between 1975 and 1979 are used. Baseline is 1990.

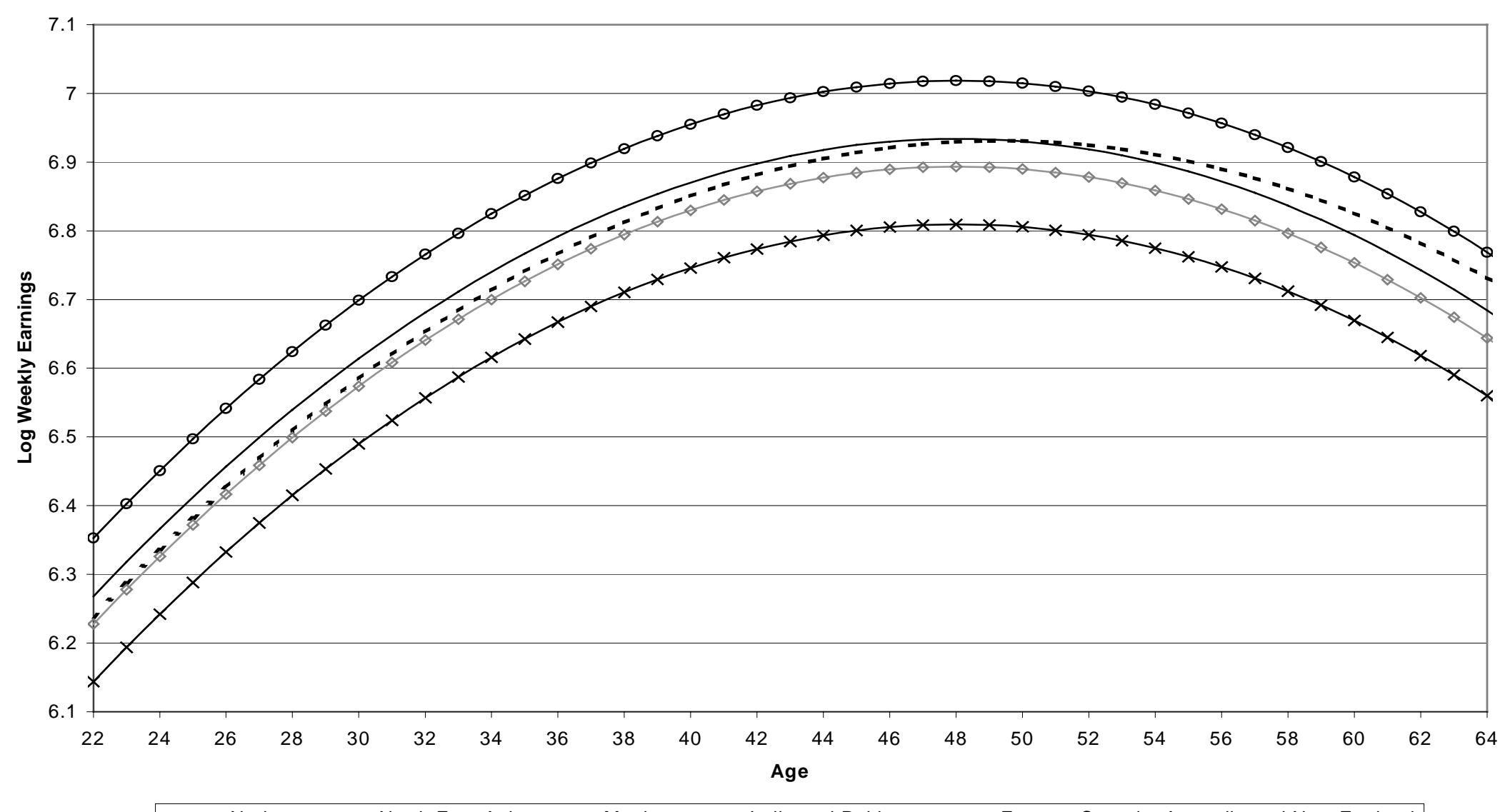

- - - Natives — North East Asia $\longrightarrow$ Mexico $\leadsto$ India and Pakistan $\multimap$ Europe, Canada, Australia and New Zealand 


\section{IZA Discussion Papers}

No. Author(s)

71

72

L. Goerke

J. Fersterer

R. Winter-Ebmer

73

G. S. Epstein

S. Nitzan

74 M. Kräkel

75

B. Henry

M. Karanassou

D. J. Snower

76

G. Brunello

M. Giannini

77

C. M. Schmidt

78

J. Hansen

R. Wahlberg

79

J. S. Earle

Z. Sakova

80 J. C. van Ours

J. Veenman

81

T. J. Hatton

S. Wheatley Price

82 K. A. Konrad

83

R. Euwals

84

C. M. Schmidt

85 S. Pudney

M. A. Shields

86

J.P. Haisken-DeNew

C. M. Schmidt

87
Title

Area

Date

The Wedge

3

$11 / 99$

Are Austrian Returns to Education Falling Over

Time?

The Endogenous Determination of Minimum Wage 3

Strategic Mismatches in Competing Teams

5

Adjustment Dynamics and the Natural Rate: An 1

Account of UK Unemployment

Selective Schools

5

Knowing What Works: The Case for Rigorous

Program Evaluation

Endogenous Schooling and the Distribution of the Gender Wage Gap

Entrepreneurship from Scratch: Lessons on the Entry Decision into Self-Employment from Transition Economies

The Netherlands: Old Emigrants - Young Immigrant Country

Migration, Migrants and Policy in the United Kingdom

Privacy, time consistent optimal labor income taxation and education policy

Female Labour Supply, Flexibility of Working Hours, 1 and Job Mobility in the Netherlands

The Heterogeneity and Cyclical Sensitivity of 1 Unemployment: An Exploration of German Labor Market Flows

Gender and Racial Discrimination in Pay and 5/6 Promotion for NHS Nurses

Money for Nothing and Your Chips for Free?

5 The Anatomy of the PC Wage Differential

Educational Mismatch and Wages in Germany
5

$11 / 99$

$11 / 99$

$12 / 99$

$12 / 99$

$12 / 99$

$12 / 99$

$12 / 99$

$12 / 99$

$12 / 99$

$12 / 99$

$12 / 99$

$12 / 99$

12/99

$12 / 99$

$12 / 99$

$12 / 99$ 
P. Cahuc

A. Zylberberg

97

A. Barrett

98

J.P. Haisken-DeNew

C. M. Schmidt

L. Husted

H. S. Nielsen

M. Rosholm

N. Smith
G. Brunello
C. Graziano
B. Parigi

Migration in Spain: Historical Background and 1 Current Trends

Aliyah to Israel: Immigration under Conditions of 1 Adversity

Tenures that Shook the World: Worker Turnover in $\quad 4$ Russia, Poland and Britain

Identification and Estimation of Causal Effects of 6 Multiple Treatments Under the Conditional Independence Assumption

The Rate of Return to Private Schooling

An Evaluation of Public-Sector-Sponsored

\section{Germany}

An Evaluation of Public Employment Programmes 6 in the East German State of Sachsen-Anhalt

Job Protection, Minimum Wage and Unemployment 3

Irish Migration: Characteristics, Causes and 1

Industry Wage Differentials Revisited: A

Longitudinal Comparison of Germany and USA

Residential Location and Youth Unemployment: 1

The Economic Geography of School-to-Work-

Transitions

Immigrant Assimilation and Welfare Participation: 1/3

Do Immigrants Assimilate Into or Out-of Welfare?

Employment and Wage Assimilation of Male First 3 Generation Immigrants in Denmark

Labor Supply and Matching Rates for Welfare

Characteristics

Estimation in a Duration Model for Evaluating

Matching Model with Uncertainty -

An Extension of Mortensen and Pissarides (1994)

Ownership or Performance: What Determines 1 
1979 - 1990: An analysis of the (West-)German multivariate failure times and unobserved heterogeneity

107 J. C. van Ours G. Ridder

J. Boone

J. C. van Ours

G. J. van den Berg

B. van der Klaauw

110 D. DeVoretz

C. Werner

111 V. Sorm

K. Terrell

L. Bellmann

T. Schank

113 R. Euwals

114 G. Brunello

A. Medio

115 A. Cigno

F. C. Rosati

116 C. Belzil

117 S. Bender

A. Haas

C. Klose

118 M. A. Shields

M. E. Ward

119 A. Lindbeck

D. J. Snower

120 P. T. Pereira

P. S. Martins

121 J. C. van Ours

122 D. Munich

J. Svejnar

K. Terrell

123 J. Hunt
Fast Track or Failure: A Study of the Completion

Rates of Graduate Students in Economics

Modeling Financial Incentives to Get Unemployed Back to Work

Combining Micro and Macro Unemployment

Duration Data

A Theory of Social Forces and Immigrant Second

Language Acquisition

Sectoral Restructuring and Labor Mobility:

A Comparative Look at the Czech Republic

Innovations, Wages and Demand for

Heterogeneous Labour: New Evidence from a

Matched Employer-Employee Data-Set

Do Mandatory Pensions Decrease Household

Savings? Evidence for the Netherlands

An Explanation of International Differences in

Education and Workplace Training

Why do Indian Children Work, and is it Bad for

Them?

Unemployment Insurance and Subsequent Job

Duration: Job Matching vs. Unobserved

Heterogeneity

IAB Employment Subsample 1975-1995.

Opportunities for Analysis Provided by the

Anonymised Subsample

Improving Nurse Retention in the British National

Health Service: The Impact of Job Satisfaction on

Intentions to Quit

The Division of Labor and the Market for

Organizations

Does Education Reduce Wage Inequality?

Quantile Regressions Evidence from Fifteen

European Countries

Do Active Labor Market Policies Help Unemployed Workers to Find and Keep Regular Jobs?

Returns to Human Capital under the Communist

Wage Grid and During the Transition to a Market

Economy

Why Do People Still Live in East Germany?
3

5

$2 / 00$

5

$2 / 00$

5

$2 / 00$

$1 / 00$

$1 / 00$

$1 / 00$

$2 / 00$

$2 / 00$

$2 / 00$

$2 / 00$

$2 / 00$

$2 / 00$

$2 / 00$

$2 / 00$

7

/00

$3 / 00$

$4 / 6$

4

$3 / 00$ 
Rational Poverty or Poor Rationality? The Take-up

125 F. Büchel

J. R. Frick

of Social Assistance Benefits

The Income Portfolio of Immigrants in Germany - $\quad 1 / 3$

$3 / 00$

Effects of Ethnic Origin and Assimilation. Or:

Who Gains from Income Re-Distribution?

126 J. Fersterer

R. Winter-Ebmer

Smoking, Discount Rates, and Returns to

Education

127 M. Karanassou

D. J. Snower

Characteristics of Unemployment Dynamics: The

Chain Reaction Approach

128 O. Ashenfelter

Do Unemployment Insurance Recipients Actively

Seek Work? Evidence From Randomized Trials in

D. Ashmore

O. Deschênes

129 B. R. Chiswick

M. E. Hurst

130 G. Brunello

S. Comi

C. Lucifora

Four U.S. States

The Employment, Unemployment and

Unemployment Compensation Benefits of

$1 / 3 \quad 3 / 00$

Immigrants

The Returns to Education in Italy: A New Look at $5 \quad 3 / 00$

the Evidence

Are Immigrants Favorably Self-Selected? An $\quad 1 \quad 3 / 00$

Economic Analysis

Hours and Wages in the Depression: British $7 \quad 3 / 00$

Engineering, 1926-1938

Paid and Unpaid Overtime Working in Germany and $1 \quad 3 / 00$

133 D. N. F. Bell

R. A. Hart

O. Hübler

W. Schwerdt

134 A. D. Kugler

G. Saint-Paul

135 A. Barrett

P. J. O'Connell

the UK

Hiring and Firing Costs, Adverse Selection and

3

$3 / 00$

Long-term Unemployment

Is There a Wage Premium for Returning Irish

1

$3 / 00$

Migrants?

136 M. Bräuninger

M. Pannenberg

Unemployment and Productivity Growth: An

3

$3 / 00$

Empirical Analysis within the Augmented Solow

Model

137 J.-St. Pischke

Continuous Training in Germany

$3 / 00$

138 J. Zweimüller

R. Winter-Ebmer

Firm-specific Training: Consequences for Job

Mobility

139 R. A. Hart

Y. Ma

Wages, Hours and Human Capital over the

Life Cycle

5

$3 / 00$

Education and Earnings Growth: Evidence from 11

European Countries

The Effects of Public Sector Sponsored Training on

Individual Employment Performance in East

$4 / 00$ 

both Worlds?

$\begin{array}{cl}145 & \text { M.-S. Yun } \\ 146 & \begin{array}{l}\text { T. K. Bauer } \\ \text { J.P. Haisken-DeNew }\end{array} \\ 147 & \begin{array}{l}\text { M. Belot } \\ \text { J. C. van Ours }\end{array}\end{array}$

Decomposition Analysis for a Binary Choice Model

Does the Recent Success of Some OECD

Microeconometric Evaluation of the Active Labour 6 Market Policy in Switzerland

The Duration of Immigrants' Unemployment Spells: $\quad 1 / 3 \quad 5 / 00$

155 J. Hansen

156 C. Dustmann Evidence from Sweden

Language Proficiency and Labour Market Per- 1

M. Jäntti

O. Raaum

E. Österbacka

Finland, Norway and Sweden Compared to the United States 
A Comparison of the Human Capital and Signaling Models: The Case of the Self-Employed and the Increase in the Schooling Premium in the 1980's

Public Employment and Redistributive Politics: 4

Racial Harassment, Job Satisfaction and Intentions to Quit: Evidence from the British Nursing Profession

Social Harmony at the Boundaries of the Welfare 3 State: Immigrants and Social Transfers

169 R. Winkelmann

Immigration Policies and their Impact: The Case of 1 New Zealand and Australia 